\title{
EXPERIMENTAL STUDY OF FLEXURAL STRENGTH OF REINFORCED CONCRETE BEAM INCORPORATING ULTRAFINE SLAG
}

\author{
Saurav $^{\# 1}$, Dr. Ashok Kumar Gupta ${ }^{\# 1}$ \\ \#Department of civil engineering, Jaypee University of Information Technology, Solan, India \\ 1ersauravsupstar@gmail.com \\ 1akgjuit@gmail.com
}

\begin{abstract}
There have been enormous researches going on the use and utilization of industrial, agricultural and thermoelectric plant residues in the production of concrete. Production of high performance concrete (HPC) plays an important role with different pozzolanic materials like fly ash, condensed silica fume, blastfurnaceslag, rise husk ash etc. There has been increase in the consumption of mineral admixture by cement and concrete industries. This rate is expected to increase day by day. The presence of mineral admixture in concrete is known to impart significant improvement in workability and durability in concrete. The present paper involves the use of mineral admixture 'ultrafine slag" as a cementitous material for cement and to evaluate the threshold limit of replacement of cement. Main aim of this work is to evaluate the flexural strength of High strength concrete by partial replacement of cement $(0,8,10$, 12, and 14\%) with ultra-fine slag (Alccofine 1203) for M60 grade of concrete.OPC of 43grade from single source is used in this investigation. The properties of cement tested as per IS4031:1988 and found to conform various specifications of IS12269:1987. Locally available river sand is used as fine aggregate and also its specific gravity and fineness is determined. The addition of alccofine shows an early strength gaining properties with increase flexural strength of concrete.
\end{abstract}

Keyword - Alccofine-1203, Flexural Strength, Ordinary Portland cement, Plain Concrete Beams, Reinforced Concrete Beams.

\section{INTRODUCTION}

Definition of concrete has been changed with passage of time and with new researches. Concrete is no longer made of cement aggregate and water only. It has to incorporate at least one of the addition ingredients such as admixtures supplementary cementitious material or fibers to enhance its strength and durability. There is great demand of high performance and highly durable concrete during recent past. The use of mineral admixture in combination with chemical admixture has allowed the concrete technologists to tailor the concrete for many specific requirements. The use of supplementary cementitious material (SCM) for cement replacement has dramatically increased along with the development of concrete industry, due to the consideration of cost saving, energy saving, environmental protection \& conservation of resources. The large scale production of cement is adding to environmental problems in one hand \& depleting the natural resources on the other. This threat to the ecology has lead researchers to utilize the industrial bi-product such as SCM in making concrete eco-friendly. Mineral admixtures generally used are fly ash, rice husk ash, metakoline, silica fume etc. Addition of such materials improves the strength and durability of concrete. Amongst the different mineral admixtures silica fume has proved to be most useful for high strength and high performance concrete due to its availability in finely divided state and very high percentage of amorphous silica. Only major disadvantage is that is it imported therefore very costly. In this work an attempt has been made to find a suitable alternate of Ultra fine slag.

\section{ULTRAFINE SLAG (ALCCOFINE 1203)}

Slag is a byproduct of steel industries. It is a nonmetallic product consisting essentially of silicates and aluminates of calcium and other bases. The molten slag is rapidly cooled down by quenching water and as a result glassy sand like granulated material is formed. The granulated material is further ground to less than 45 micron to have will have specific surface area of about 400 to $600 \mathrm{~m}^{2} / \mathrm{kg}$ (Blaine).This slag after grinding is termed as ground granulated blast furnace slag (GGBS) The performance of slag largely depends on the chemical composition, glass content and fineness of grinding. The quality of slag is governed by IS 12089 of 1987.Ultra fine slag is more advanced form of GGBS in which slag is further ground to less than 20 micron. As a result its specific surface area is increased dramatically to $3000-5000 \mathrm{~m}^{2} / \mathrm{kg}$ (Bet Analysis). Particle shape of ultrafine slag is spherical (Scanning electron microscope) which due to ball bearing effect gives increased workability at much reduced water content. 
A joint venture with Ambuja cement ltd and Alcon developers produces ultrafine slag with a brand name Alccofine.It is manufactured in the controlled conditions with special equipments to produce optimized particle size distribution which is its unique property.Alccofine 1203 and Alccofine 1101 are two types of Alccofine with low calcium silicate and high calcium silicate respectively. Alccofine 1200 series is of 1201, 1202, 1203 which represents fine, micro fine, ultrafine particle size respectively. Alccofine 1203 is slag based SCM having ultra fineness with optimized particle size distribution whereas Alccofine 1101 is a micro finer cementitious grouting material for soil stabilization and rock anchoring. The performance of Alccofine is superior to all the other admixtures used in India.

TABLE I. Physical parameters of Alccofine1203

\begin{tabular}{|c|c|c|c|c|}
\hline Specific gravity & Bulk Density (kg/m3) & \multicolumn{3}{|c|}{ Particle size distribution in micron } \\
\hline 2.9 & $600-700$ & $\mathrm{~d}_{10}$ & $\mathrm{~d}_{50}$ & $\mathrm{~d}_{90}$ \\
\cline { 2 - 5 } & & $1-2$ & $4-5$ & $8-9$ \\
\hline
\end{tabular}

\section{III.SCOPE OF THE WORK}

The main and foremost objective of the present investigation is to evaluate the threshold limit of replacement of cement. Flexural strength of Reinforced cement concrete beam is carried out with partial replacement of cement by alccofine 1203. In this paper RCC beam of $500 \mathrm{~mm} \times 100 \mathrm{~mm} \times 100 \mathrm{~mm}$ is used and investigation targets to determine the optimum percentage $(0,8,10,12$, and $14 \%)$ of alccofine as a partial replacement of cement for M60 grade of concrete.

\section{EXPERIMENTAL WORK}

\section{Materials}

Ordinary Portland cement (OPC) of 43 Grade from single source was used in this investigation. The properties of cement tested as per IS: 8112:1989

TABLE II. Physical properties of cement

\begin{tabular}{|c|c|}
\hline Property & Result \\
\hline Specific gravity & 3.15 \\
\hline Normal consistency (P): & $32 \%$ \\
\hline Setting times & \\
Initial setting times & $62 \mathrm{mins}$ \\
Final setting times & $260 \mathrm{mins}$ \\
\hline Fineness of cement & $5 \%$ retained \\
(By 90 micron sieve) & \\
\hline Soundness of cement & $2 \mathrm{~mm}$ \\
\hline & \\
Compressive Strength & \\
7 Days & $29 \mathrm{~N} / \mathrm{mm}^{2}$ \\
28 Days & $47 \mathrm{~N} / \mathrm{mm}^{2}$ \\
\hline
\end{tabular}

The locally available river sand with specific gravity 2.66 and fineness modulus 2.5 was used as a fine aggregate. The compacted bulk density value is $1620 \mathrm{Kg} / \mathrm{m}^{3}$.The crushed stone aggregate with maximum size $20 \mathrm{~mm}$ having specific gravity and fineness modulus 2.68 and 6.7 respectively was used. Steel reinforcement used were $8 \mathrm{~mm}$ dia bars as main reinforcement and $6 \mathrm{~mm}$ dia bars as stirrups

\section{Mix proportion}

The mix proportion of M60 Grade concrete was designed based on the recommendation of IS10262: 1982 without alccofine. The identification of mix proportions and quantity of materials taken for $1 \mathrm{~m}^{3}$ of concrete mixes are given in table 3 and table 4 . Concrete mixes were prepared with cement replacement of $0,8,10,12$, and $14 \%$ by alccofine.

\section{Preparation of Test Specimen}

The ingredients for various mixes were weighed and mixes prepared by using tilting drum type concrete mixes machine. Precautions were taken to ensure uniform mixing of ingredients. The specimen were cast in steel moulds of size $500 \mathrm{~mm} \times 100 \mathrm{~mm} \times 100 \mathrm{~mm}$. 2 bars of $8 \mathrm{~mm}$ dia as main reinforcement was used as main reinforcement shown in the Fig1 along with vertical stirrups of 6mm dia @150mm c/c. 
TABLE III. Beam nomenclature

\begin{tabular}{|c|c|}
\hline Plain concrete beams & R/F concrete beams \\
\hline C0 $-0 \%$ & R0 $-0 \%$ \\
\hline C8 $-08 \%$ & R8 $-08 \%$ \\
\hline C10 $-10 \%$ & R10 $-10 \%$ \\
\hline C12 - $12 \%$ & R12 - $12 \%$ \\
\hline C14 - $14 \%$ & R14 - $14 \%$ \\
\hline
\end{tabular}

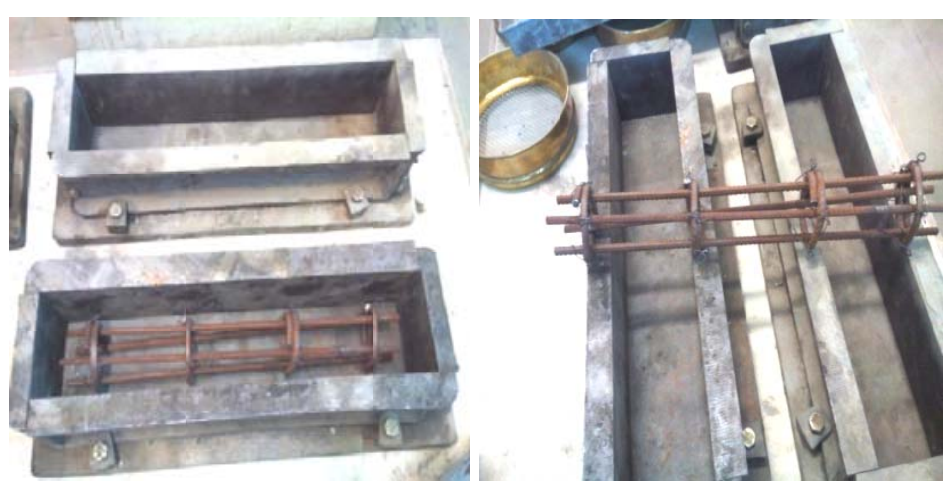

Fig. 1. Size of Mould for beam - 500 mmx100mmx100 mm R/F -- 8 mm (Longitudinal) at effective cover of 20mm and 6 mm (Stirrups) @ $150 \mathrm{~mm} \mathrm{c} / \mathrm{c}$

TABLE IV. Mix proportion for M60 grade mixture

\begin{tabular}{|c|c|c|c|c|c|}
\hline Mix Designation & C0 & C8 & C10 & C12 & C14 \\
\hline Alccofine $\%$ & 0 & 8 & 10 & 12 & 14 \\
\hline Free w/c Ratio & 0.30 & 0.30 & 0.30 & 0.30 & 0.30 \\
\hline Cement $\left(\mathrm{Kg} / \mathrm{m}^{3}\right)$ & 480 & 456 & 432 & 422.4 & 412.8 \\
\hline Alccofine $\left(\mathrm{Kg} / \mathrm{m}^{3}\right)$ & 0 & 24 & 48 & 57.6 & 67.2 \\
\hline Sand $\left(\mathrm{Kg} / \mathrm{m}^{3}\right)$ & 644 & 592.5 & 542.71 & 506.59 & 472.13 \\
\hline Coarse Aggregate $\left(\mathrm{Kg} / \mathrm{m}^{3}\right)$ & 1127 & 1127 & 1127 & 1127 & 1127 \\
\hline Water $\left(\mathrm{lit} / \mathrm{m}^{3}\right)$ & 144 & 144 & 144 & 144 & 144 \\
\hline
\end{tabular}

\section{TEST RESULTS AND DISCUSSION}

\section{Flexural Strength Test}

The beam flexural strength was made as per the IS: 516-1959 specification by flexural machine for different proportion of concrete mix. For this study the concrete beams of size $500 \mathrm{~mm} \times 100 \mathrm{~mm} \times 100 \mathrm{~mm}$ were prepared. Total 45 Nos.of beams were casted for each grade and each type i.e Plain concrete beam and reinforced concrete beam to be tested at different ages of curing. Reinforcement used was 2 bars of $8 \mathrm{~mm}$ dia as main reinforcement and vertical stirrups using 6mm dia @150mm c/c was used.Beams were cured for 7, 14\& 28 days time age. The beams were placed normal to the casting and symmetrical two point system was adopted for the flexural tensile strength test. The deflection of the beams was measured by the dial gauge of least count of $0.01 \mathrm{~mm}$, which was placed in the middle third portion of the beam. Average flexural strength plain and reinforced concrete showed an improved flexural strength up to $12 \%$ replacement. The resulting values of both Plain and reinforced concrete beams are tabulated below

TABLE V. Flexural strength of Plain concrete mixes incorporating alccofine at 7, 14, 28 Days

\begin{tabular}{|c|c|c|c|c|c|c|}
\hline \multirow{2}{*}{ MIX } & \multicolumn{3}{|c|}{ Flexural strength $\left(\mathrm{N} / \mathrm{mm}^{2}\right)$} & \multicolumn{3}{|c|}{ Average Flexural strength $\left(\mathrm{N} / \mathrm{mm}^{2}\right)$} \\
\hline & 7 days & 14 days & 28 days & 7 days & 14 days & 28 days \\
\hline \multirow{3}{*}{$\mathrm{C} 0$} & 1.32 & 3.01 & 5.79 & \multirow{3}{*}{1.27} & \multirow{3}{*}{2.69} & \multirow{3}{*}{5.59} \\
\hline & 1.22 & 2.09 & 5.32 & & & \\
\hline & 1.28 & 2.98 & 5.66 & & & \\
\hline \multirow{2}{*}{ C 8} & 1.51 & 3.10 & 6.23 & \multirow{2}{*}{1.34} & \multirow{2}{*}{2.93} & \multirow{2}{*}{6.26} \\
\hline & 1.45 & 2.75 & 6.43 & & & \\
\hline
\end{tabular}




\begin{tabular}{|c|c|c|c|c|c|c|}
\hline & 1.06 & 2.94 & 6.12 & & & \\
\hline \multirow{3}{*}{ C 10} & 1.59 & 3.48 & 6.50 & \multirow{3}{*}{1.45} & \multirow{3}{*}{3.25} & \multirow{3}{*}{7.14} \\
\hline & 1.23 & 2.97 & 7.40 & & & \\
\hline & 1.53 & 3.30 & 7.52 & & & \\
\hline \multirow{3}{*}{ C 12} & 1.70 & 3.80 & 8.56 & \multirow{3}{*}{1.58} & \multirow{3}{*}{3.58} & \multirow{3}{*}{8.14} \\
\hline & 1.13 & 3.23 & 8.14 & & & \\
\hline & 1.91 & 3.71 & 7.72 & & & \\
\hline \multirow{3}{*}{ C 14} & 1.53 & 3.65 & 8.23 & \multirow{3}{*}{1.55} & \multirow{3}{*}{3.51} & \multirow{3}{*}{7.92} \\
\hline & 1.48 & 3.35 & 8.01 & & & \\
\hline & 1.64 & 3.53 & 7.52 & & & \\
\hline
\end{tabular}

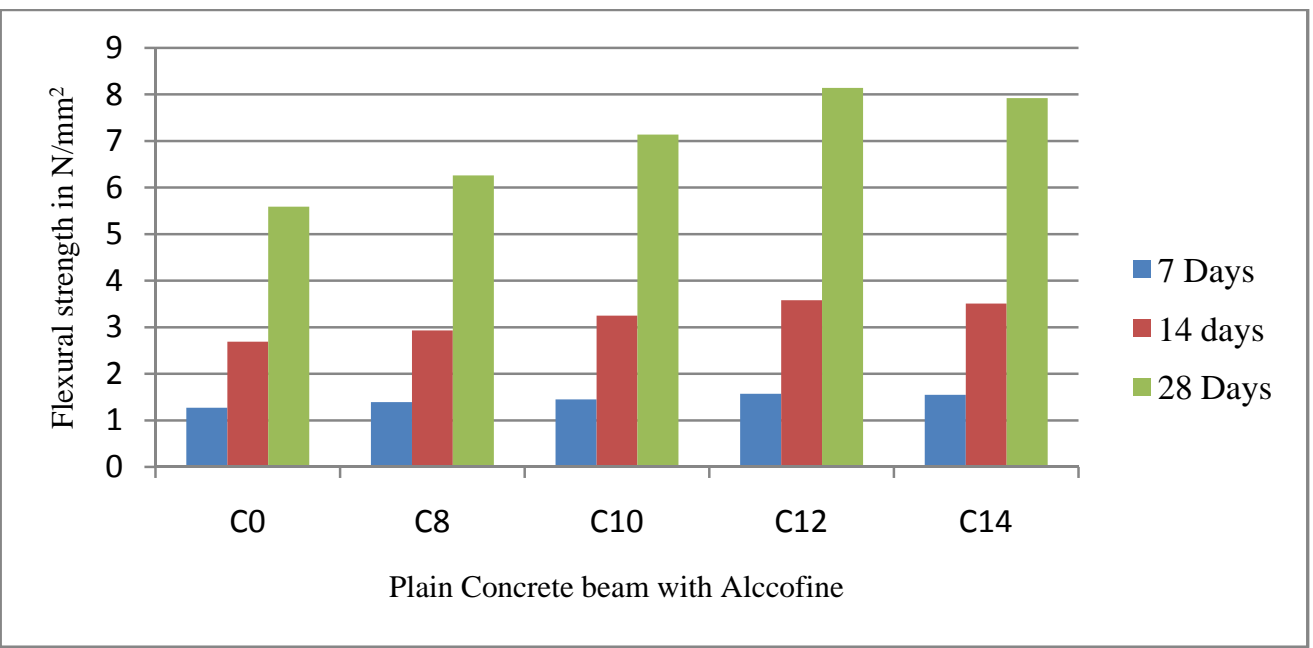

Fig. 2. Variation of Flexural strength of plain concrete with different \% of alccofine

TABLE VI. Flexural strength of Reinforced concrete mixes incorporating alccofine at 7, 14, 28 days

\begin{tabular}{|c|c|c|c|c|c|c|}
\hline \multirow{2}{*}{ Mix } & \multicolumn{3}{|c|}{ Flexural strength $\left(\mathrm{N} / \mathrm{mm}^{2}\right)$} & \multicolumn{3}{|c|}{ Average Flexural strength $\left(\mathrm{N} / \mathrm{mm}^{2}\right)$} \\
\hline & 7 days & 14 days & 28 days & 7 days & 14 days & 28 days \\
\hline \multirow{3}{*}{ R0 } & 3.15 & 8.57 & 18.14 & \multirow{3}{*}{3.02} & \multirow{3}{*}{8.34} & \multirow{3}{*}{18.05} \\
\hline & 2.89 & 8.42 & 17.92 & & & \\
\hline & 3.02 & 8.03 & 18.09 & & & \\
\hline \multirow{3}{*}{ R 8} & 3.44 & 8.65 & 18.01 & \multirow{3}{*}{3.21} & \multirow{3}{*}{8.99} & \multirow{3}{*}{20.49} \\
\hline & 3.45 & 9.05 & 21.35 & & & \\
\hline & 2.74 & 9.27 & 22.11 & & & \\
\hline \multirow{3}{*}{$\mathrm{R} 10$} & 3.78 & 11.12 & 25.65 & \multirow{3}{*}{3.55} & \multirow{3}{*}{10.10} & \multirow{3}{*}{23.95} \\
\hline & 3.15 & 8.89 & 21.12 & & & \\
\hline & 3.72 & 10.29 & 25.08 & & & \\
\hline \multirow{3}{*}{$\mathrm{R} 12$} & 4.89 & 12.75 & 28.36 & \multirow{3}{*}{4.06} & \multirow{3}{*}{11.84} & \multirow{3}{*}{29.34} \\
\hline & 3.15 & 11.06 & 30.15 & & & \\
\hline & 4.14 & 11.71 & 29.51 & & & \\
\hline \multirow{3}{*}{ R 14} & 4.44 & 11.75 & 28.30 & \multirow{3}{*}{3.99} & \multirow{3}{*}{11.68} & \multirow{3}{*}{28.98} \\
\hline & 4.06 & 10.73 & 30.15 & & & \\
\hline & 3.47 & 12.56 & 28.49 & & & \\
\hline
\end{tabular}




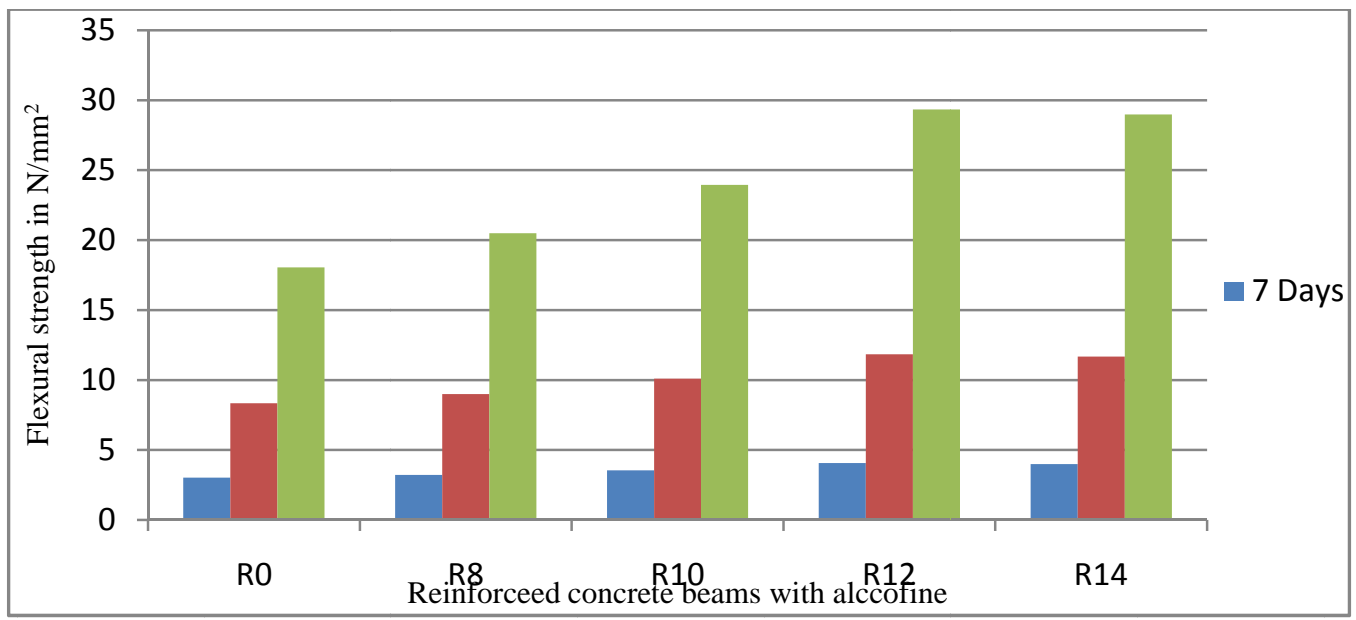

Fig . 3. Variation of Flexural strength of Reinforced concrete with different \% of alccofine

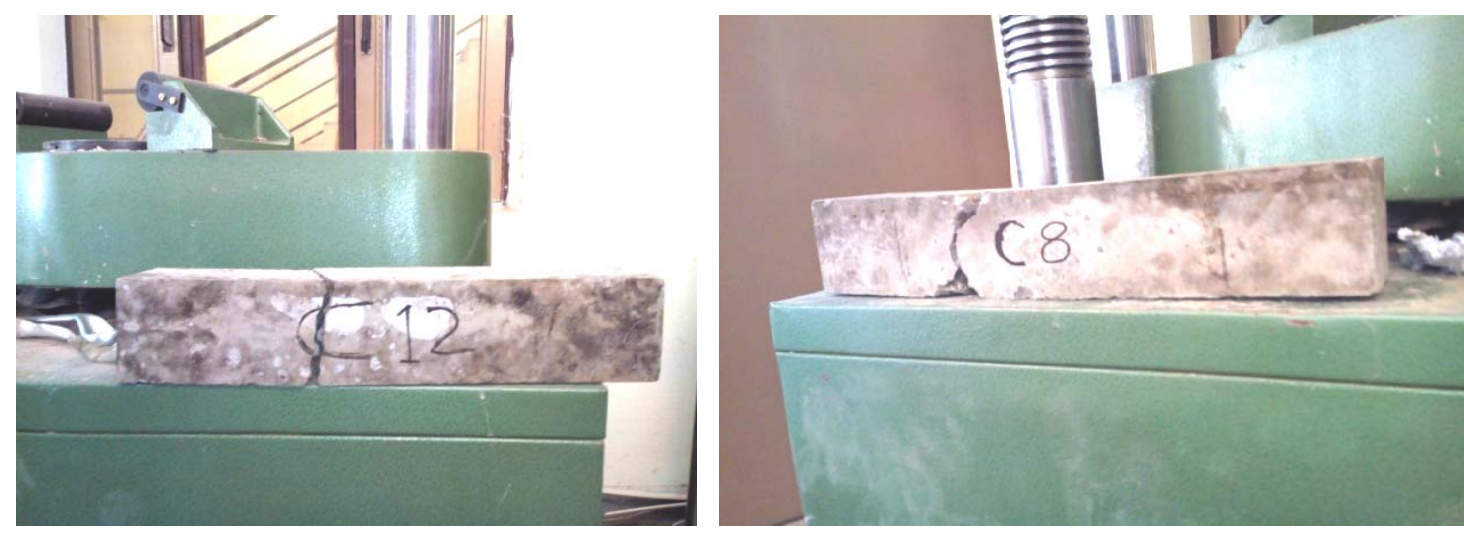

Fig. 4. Failure observed in Plain Concrete Beams
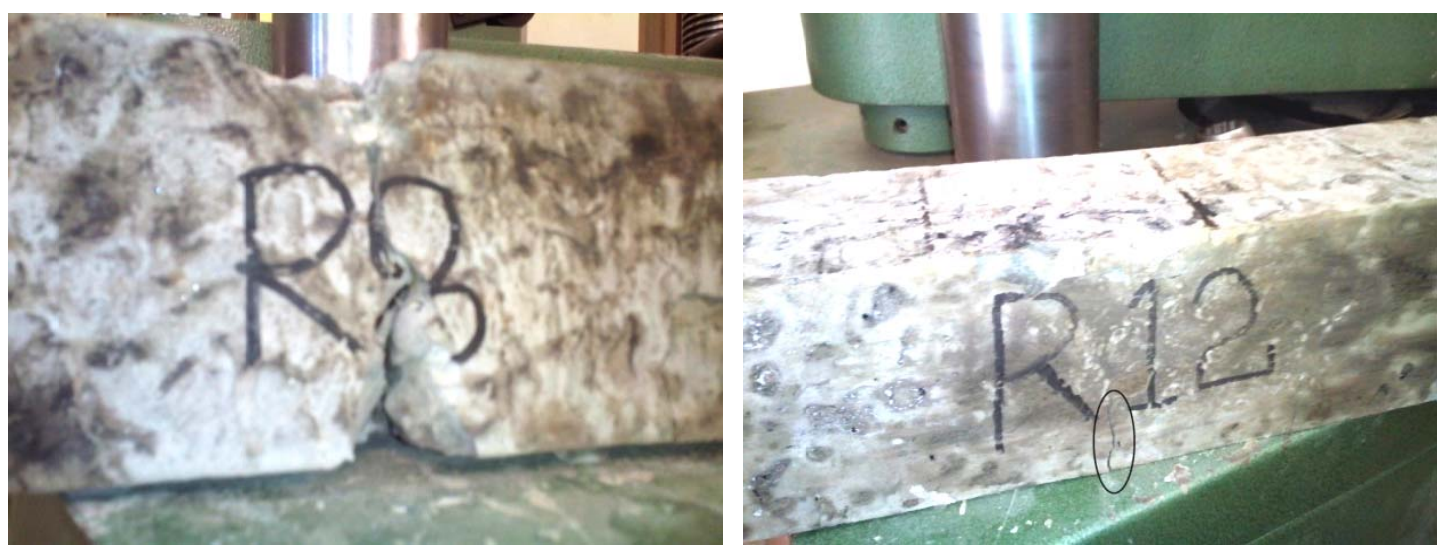

Fig. 5. Failure Of Reinforced Concrete Beam

TABLE VII. \% change in Flexure strength of M60 grade ofPlain concrete compared with controlled concrete

\begin{tabular}{|c|c|c|}
\hline Mix & $\mathbf{7}$ days & 28 Days \\
\hline C0 & - & - \\
\hline C8 & 5.5 & 11.9 \\
\hline C10 & 8.2 & 14.05 \\
\hline C12 & 8.9 & 15.96 \\
\hline C14 & -1.9 & -2.70 \\
\hline
\end{tabular}


TABLE VIII. \% change in Flexure strength of M60 grade of Reinforced concrete compared with controlled concrete

\begin{tabular}{|c|c|c|}
\hline Mix & 7 days & 28 Days \\
\hline R0 & - & - \\
\hline R8 & 6.5 & 13.5 \\
\hline R10 & 10.5 & 16.9 \\
\hline R12 & 14.4 & 22.5 \\
\hline R14 & -1.5 & -1.2 \\
\hline
\end{tabular}

TABLE IX. Load Vs Deflection values

\begin{tabular}{|c|c|c|c|c|}
\hline \multirow{2}{*}{ Deflection(mm) } & \multicolumn{4}{|c|}{ Load(kN) } \\
\cline { 2 - 5 } & $\mathbf{C 0}$ & $\mathbf{C 1 2}$ & $\mathbf{R 0}$ & $\mathbf{R 1 2}$ \\
\hline 0.4 & 14.8 & 21.7 & 15.7 & 16.9 \\
\hline 0.8 & 18.9 & 24.5 & 17.2 & 24.1 \\
\hline 1.2 & 22.2 & 30.4 & 22.3 & 30.3 \\
\hline 1.6 & 24.5 & 31.0 & 29.9 & 39.0 \\
\hline
\end{tabular}
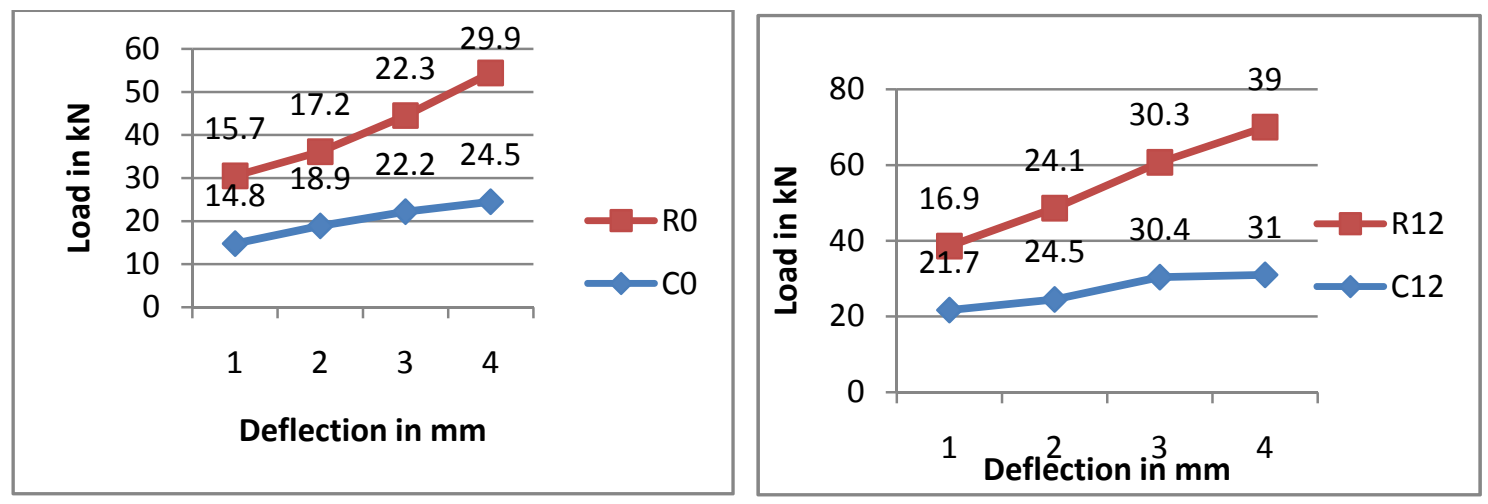

Fig. 6. Variation of load vs. deflection for controlled concrete and $12 \%$ Alccofine

\section{CONCLUSION}

The tests performed to check the Flexural performance of Alccofine as a cement replacement can be conclude as follows

1. Alccofine not only improves the compressive strength of concrete but also improves its flexural strength at much lower water cement ratio as compared to Controlled concrete. It also increases the workability of concrete at much lower w/c ratio due to ball bearing effect.

2. There is considerable change in flexural strength of RCC beam as compared to plain concrete beam incorporating same \% of Alccofine. At $12 \%$ of alccofine there is maximum increase in flexural strength of RCC beam i.e. $22.5 \%$.

3. Alccofine has better performance as compared to other slag materials and micro silica. It is helpful to make concrete workable. By replacing cement with alccofine there is considerable increase in workability of concrete without adding any plasticizers.

4. A control on deflection has been achieved in both the R/F \& plain concrete beams when incorporated with alccofine without losing its strength. A higher loading was required to produce same amount of deflection in both cases.

\section{REFERENCES}

[1] Shukla H, et al ; Optimum dose of metakaolin in steel fiber reinforced Portland pozzolona cement concrete ; Journal of Academia and Industrial Research Volume 3, Issue 5 October 2014

[2] Jamnu M.A, et al ; Effect on Compressive strength of high performance concrete incorporating alccofine and fly Ash, International journal of innovative research and development Volume 3, Issue 2 February 2014

[3] Pawar M.S, et al, "performance of self compacting concrete using alccofine”, International journal of engineering Research and application, Aug 2013

[4] Solanki J.V Singh, et al ; Flexural strength of beams by partial replacement of cement with fly ash and hypo sludge in concrete ; International Journal of Engineering Science and Innovative Technology (IJESIT) Volume 2, Issue 1, January 2013

[5] Madhavi T.P,et al; Partial replacement of cement and fine aggregate by using fly ash and glass aggregate : IJRET: International Journal of Research in Engineering and Technology eISSN: 2319-1163 | pISSN: 2321-7308, November 2013 
[6] Shende A.M.et al; Experimental Study on Steel Fiber Reinforced Concrete for M-40 Grade; International Refereed Journal of Engineering and Science (IRJES) ISSN 2319-183X, Volume 1, Issue 1 September 2012

[7] Roy D.K, et al ; Effect of Partial Replacement of Cement by Silica Fume on Hardened Concrete ; International Journal of Emerging Technology and Advanced Engineering, ISSN 2250-2459, Volume 2, Issue 8, August 2012

[8] Shukla Abhilash, et al ; Study of the Properties of Concrete by Partial Replacement of Ordinary Portland Cement by Rice Husk Ash, International journal of Earth science and engineering, Volume 4 no 6 SPL, October 2011

[9] Selc, Uk TuRkel et al ; The effect of limestone powder, fly ash and silica fume on the properties of self-compacting repair mortars ; Sadhana Vol. 34, Part 2, April 2009, pp. 331/333

[10] Reddy B.D, et al "An Experimental investigation on micro silica with flies ash on concrete strength behavior” (2006).

[11] Kaushik S. K, et al "Mechanical Properties of High Strength Concrete: A review” From: - The Indian Concrete Journal, August: 2001, Vol.: 75, No.: 8

[12] Young, J.F. (2000), “The Chemical and Micro-structural Basis for High Performance Concrete”, Proceedings of High Performance Concrete - Workability, Strength and Durability, Hong Kong 1,2000, p 87-103

[13] Shah, S.P. (2000), "High performance concrete: past, present and future", Proceedings of High Performance Concrete - Workability, Strength and Durability, Hong Kong, v 1, p 3-29

[14] Milhaud, V.M, et al (1996) “Pozzolanic and Cementitious Materials” Overseas Publishers, pp191

[15] IS: 516-1959 Methods of tests for strength of Concrete.BIS, New Delhi, India

[16] IS: 1199-1959 Methods of sampling and analysis of Concrete.BIS, New Delhi, India

[17] IS 383:1970 Specification for coarse and fine aggregates from natural sources for concrete (second revision) Jan 2007

[18] IS 2386(Part 1):1963 Methods of test for aggregates for concrete: Part 1 Particle size and shape Jan 2007

[19] IS: 4031-1988 Methods for Physical Tests for Hydraulic Cement. Bureau of Indian Standards, New Delhi, India.

[20] IS: 8112-1989 Standard Code of Practice for 43-Grade Ordinary Portland cement. Bureau of Indian Standards, New Delhi, India

[21] Indian Standard Plain and Reinforced Concrete Code of Practice”. IS 456:2000, Bureau of Indian Standards, New Delhi

[22] Indian Standard Specification for granulated slag for manufacture of Portland Slag Cement. IS 12089:1987, Bureau of Indian Standards, New Delhi 